\title{
EQUiLIBRIUM
}

Quarterly Journal of Economics and Economic Policy

2015 VOLUME 10 ISSUE 2, June

p-ISSN 1689-765X, e-ISSN 2353-3293

www.economic-policy.pl

Borowiec, A. (2015). A Model Assessing Innovativeness of Administration Units Awarding Public Contracts as a Tool to Conduct Economic Policy of the State. Equilibrium. Quarterly Journal of Economics and Economic Policy, 10(2), pp. 93-114, DOI: http://dx.doi.org/10.12775/ EQUIL.2015.015

Arkadiusz Borowiec*

Poznan University of Technology, Poland

\section{A Model Assessing Innovativeness of Administration Units Awarding Public Contracts as a Tool to Conduct Economic Policy of the State}

\section{JEL Classification: E1; E6}

Keywords: macroeconomic policy; policy making; innovation; public procurement

\begin{abstract}
In today's market economy factors concerning knowledge, new technologies and innovative solutions are essential for economic development. However, the Polish economy, despite its high innovation potential compared to other European Union countries, is characterized by a very low level of innovativeness. Implementing this potential is conditioned by an appropriate economic policy of the state and rational approach to its resources and legal solutions. One of the possibilities of such an action is the use of public procurement instrument through which it is possible to more effectively create demand for innovative products and services.

As shown by literature studies, the achievements of the subject literature associated with the creation of demand for innovations by public administration in Poland have been very modest. This gap is recognized by the article, and it attempts to build a model for assessing the innovativeness of these units. Network thinking methodology was used to build the model. As a result, after the identification of factors affecting the conduct of an innovative public procurement, a net-
\end{abstract}

(C) Copyright Institute of Economic Research \& Polish Economic Society Branch in Toruń Date of submission: December 15, 2014; date of acceptance: May 5, 2015

* Contact: arkadiusz.borowiec@put.poznan.pl, Poznan University of Technology, Faculty of Engineering Management, Chair of Economic Sciences, 11 Strzelecka Str., 60-965 Poznan, Poland 
work of links was established between them and examined in terms of type, intensity and duration of exposure. Building a model according to the methodology, the opinions of experts have been used along with long-term observations conducted in the course of participation in all kinds of conferences and trainings. The model was also subjected to validation in two selected units.

\section{Introduction}

In recent years innovativeness, has been one of the priority areas of economic policy in Poland and other EU countries. This policy, in line with the understanding of innovations as a driver of economic growth (Romer, 1986), is reflected in many documents at the Community level, as well as the actions taken by the governments of many countries. However, while analyzing the position of Poland in the ranking of the EU innovativeness, it should be noted that its economy is showing a low level of this indicator and scores the fourth place from the end in comparison to the remaining EU Member States ${ }^{1}$. Especially worrying is the insufficient activity reported in connection with the decommissioning of the institutional barriers and the lack of adapting public institutions to the needs of entrepreneurs.

It seems that there are several reasons behind the growing importance of innovations in the Polish economy. Firstly, the 20th Century witnessed a great technological revolution - especially in the field of telecommunications and informatics. This considerably accelerated the ageing process of many products and services available on the market. This situation obliges the producers to multiply their efforts to generate innovations, especially regarding products and processes, as well as rapid changes in the structure of employment. Secondly, the Polish market economy has been slowly entering a state of maturity, and after more than 22 years of operation it requires new challenges and effective actions. In order for this economy to be respected in the European Union efforts should be strengthened and expanded in order to accelerate its development and its competitive position should be improved as well. Thirdly, the beginning of the 21 st century showed how much countries like India, Brazil and China did to improve the competitiveness of their economies. To maintain its position as a strong European country Poland should, therefore, take steps to maintain and perhaps strengthen its economic position.

\footnotetext{
${ }^{1}$ The innovative position has been determined using the Innovation Union Scoreboard.
} 
As we can see, there can be numerous motives for introducing innovations and they may involve internal and external sources (Freeman, 1994). They should focus on many aspects of economic policy, including the public procurement market, which in Poland has been growing rapidly and its estimated value amounted to approximately $8.76 \%$ of gross domestic product by 2013 (PPO, 2014, p. 27). Thus, the value of this market indicates that the analysis of creating demand for innovations through public procurement system (and thus the use of the existing potential of this system) is a very important economic problem facing the Polish economy. Despite the lack of empirical achievements in this regard, the examples of highly developed countries show that through the effective use of existing resources and legal status (through solutions used by public administration) innovativeness of many economies could be raised.

This paper aims to build a model to measure the innovativeness of the Polish public administration entities based on public procurement, and using the network thinking methodology based on systems theory, which is used for the proper allocation of funds in such entities. This model is a proposal of the first in the literature system recognition of key factors related to public procurement, which affect the innovativeness of the Polish economy. Moreover, such an assessment can be useful for decision makers for an effective, and most importantly, fair allocation of budgetary resources to the bodies responsible for organizing legal tenders in our country, as well as comparing them to responses favoring the creation of demand for new products and services.

The hypothesis related to the purpose of this paper can be formulated as follows: among the conditions that exist on the public procurement market it is possible to extract those that are steerable and can actively lead to improving the innovativeness of the economy using public sector procurement.

The structure of the paper serves the verification of this very hypothesis. The article attempts to build this aforementioned model for assessing the innovativeness of public administration entities awarding public contracts against the background of theoretical considerations concerning the place of innovations in the economy.

\section{Methodology of the Research}

According to J. Gmurczyk, in case of such complex issues as innovativeness, system thinking seems to be almost necessary (Gmurczyk, 2014, p. 32). Network thinking methodology has been used to build the model to 
assess the innovativeness of public administration entities involved in public procurement. As a result, after the identification of factors affecting the conduct of an innovative public procurement, a network of links has been established between them and examined in terms of type, intensity and duration of exposure. This identification was made possible as a result of discussion in a group of experts dealing with procurement on a daily basis ${ }^{2}$.

Network thinking methodology based on the cooperation of those involved in the analysis of the problem posed in front of them, provides very objective results. In this sense, it certainly deserves to be called a moral methodology. Although it takes much more time than a simple methodology of cause and effect, it also avoids the pitfalls of linear thinking and taking "shortcuts" and finding numerous unpleasant surprises. The methodology requires the use of a simple yet very precise language. Many of the concepts, definitions and problems require, therefore, the analysis and extensive consultations of participating experts. This is of great importance when it comes to a critical attitude toward the discussed problems. As stated by A. Piekarczyk and K. Zimniewicz, the use of network thinking methodology allows us to discover the various limitations and barriers present in the decision-making process, which in the case of the provision of innovative public procurement is an extremely important issue.

\section{Innovations and Public Procurement}

In economic theory, innovation is defined in a variety ways. Schumpeter is the author of one of the most commonly used definitions. He argues that innovation is the process of converting the existing possibilities into new ideas and putting them into practical use (Schumpeter, 1995, p. 60). On the basis of this definition a number of different interpretations of the term have appeared in the subject literature.

It is worth noting that Shumpeter's theory has been dubbed a supply-side theory because he believed that the emergence of innovations determines the activity of entrepreneurs. It is in a direct contradiction with the theory of J. Schmookler, who in the sixties pointed to the relationship between the appearance of innovations and market demand. These theories were merged in the eighties by K. Oppenländer, who claimed that the innovations introduced by entrepreneurs are in minority (although they may constitute an important breakthrough); nevertheless the consumers prejudge the direction

\footnotetext{
${ }^{2}$ These people form a group of 43 postgraduate students participating in the course titled "public procurement and public-private partnerships."
} 
of changes in the production structure. This is a supply-demand theory, and it reflects very well the specifics of public procurement market. On the one hand, there are the ordering parties who create demand, and on the other contractors who represent the supply side.

Numerous distinguished scholars have been dealing with the Issues of innovation, both in Poland and abroad. They include such figures as: M. Porter, J. Kay, C.K. Prahald, H, Simon, J. Schmookler, P.F. Drucker, P. Kotler, P.R. Whitfield, Ch. Freeman, E. Mansfield, C.F. Carter, and also E. Stawasz, K. Poznańska, P. Niedzielski, W. Janasz, J. Penc, T. Baczko, S. Kwiatkowski, L.J. Jasiński, A.H. Jasiński, J. Bogdanienko or B. Gruchman.

The subject literature sources share a view according to which the Polish economy has a high potential for innovation. It consists of strong entrepreneurship of Poles (according to Eurostat, Poland is one of the most entrepreneurial countries in the world), successes of many industries in creating innovation in spite of the lack of interest of the state in financing their new ideas, as well as greater attention paid to the development of metropolitan areas, all cause changes in attitude and thinking about innovation. However, using this potential requires an appropriate economic policy of the state and a rational approach to resources and legal solutions. One possibility for an effective action is a consistent use of solutions provided by the public procurement system.

The achievements of theoretical and empirical research on creating innovation through the public procurement system are, however, very modestly represented in global literature. The issue of creating innovation by this system is addressed mainly by the EU strategic documents such as the Lisbon Strategy, while in Poland - the publications of the Polish Agency for Enterprise Development and the Ministry of Economy. However, they do not include any in-depth research and analysis indicating the possible use of the development potential within public procurement in order to create new solutions in the form of innovative products and services. It should also be noted that the literature related to procurement is dominated by all kinds of legal publications and economic issues have not been of particular interest so far.

In Poland the system of financing innovations is based mainly on donations (e.g. the European funds). There are no state tax incentives or any funding of $\mathrm{R} \& \mathrm{D}$ activities. Therefore, it seems that it is worth considering the use of public procurement as an instrument for creating innovations. As it turns out, $70 \%$ of Polish SME sector companies believe that raising funds for the implementation of innovations is difficult, and only $12.2 \%$ of them have been able to introduce innovative solutions thanks to funding from external sources. 


\section{The Construction of a Model for Assessing the Innovativeness of Polish Public Administration Entities Awarding Public Contracts}

According to the network thinking methodology, it is necessary to illustrate the problematic situation first. For the assessment of entities purchasing innovative products and services, the problematic situation is to identify the elements included in the network of connections formed by the contract with both proximal and distant environments.

Innovative public procurement had to appear in the centre of the created network, because the objective is to develop a model for assessing the innovativeness of public administration through the prism of public procurement contracts. This type of procurement is created by public institutions, which simultaneously constitute one of the most important stakeholders influencing the launch of the award of these contracts and through this prism it is necessary to assess entities awarding public contracts. The network of connections between the factors influencing the solution to the problem situation is shown in Figure 1.

The next step should be to analyze the interrelationships between the various factors in the network in accordance with the adopted network thinking methodology. From a point of view of impacts, isotropic (prefix + ) and opposite (sign-) interactions have been assumed. These designations, however, have not been provided in the figure due to their low readability.

The next step in the analysis of network thinking is to create an influence matrix (Table 1). For this purpose, it is worth using a spreadsheet, where the individual rows and columns are included in the value of the intensity of interactions between factors. Then it is necessary to add up the rows and columns that show activity (sum of $\mathrm{A}$ ) and reactivity (sum of $\mathrm{P}$ ).

High values obtained in the "sum A" column mean that the factor has a strong impact on other factors, while low values mean that its influence is small. High values obtained in the line "the sum of $\mathrm{P}$ " mean that the factor was heavily influenced, and low mean that it is subject to a weak influence of other factors.

From the point of view of the construction of a model (for assessing the innovativeness of public administration awarding public contracts) for further analysis only those factors will be admitted that constitute the two first-mentioned groups. 
Figure 1. A network of factors influencing innovative public procurements

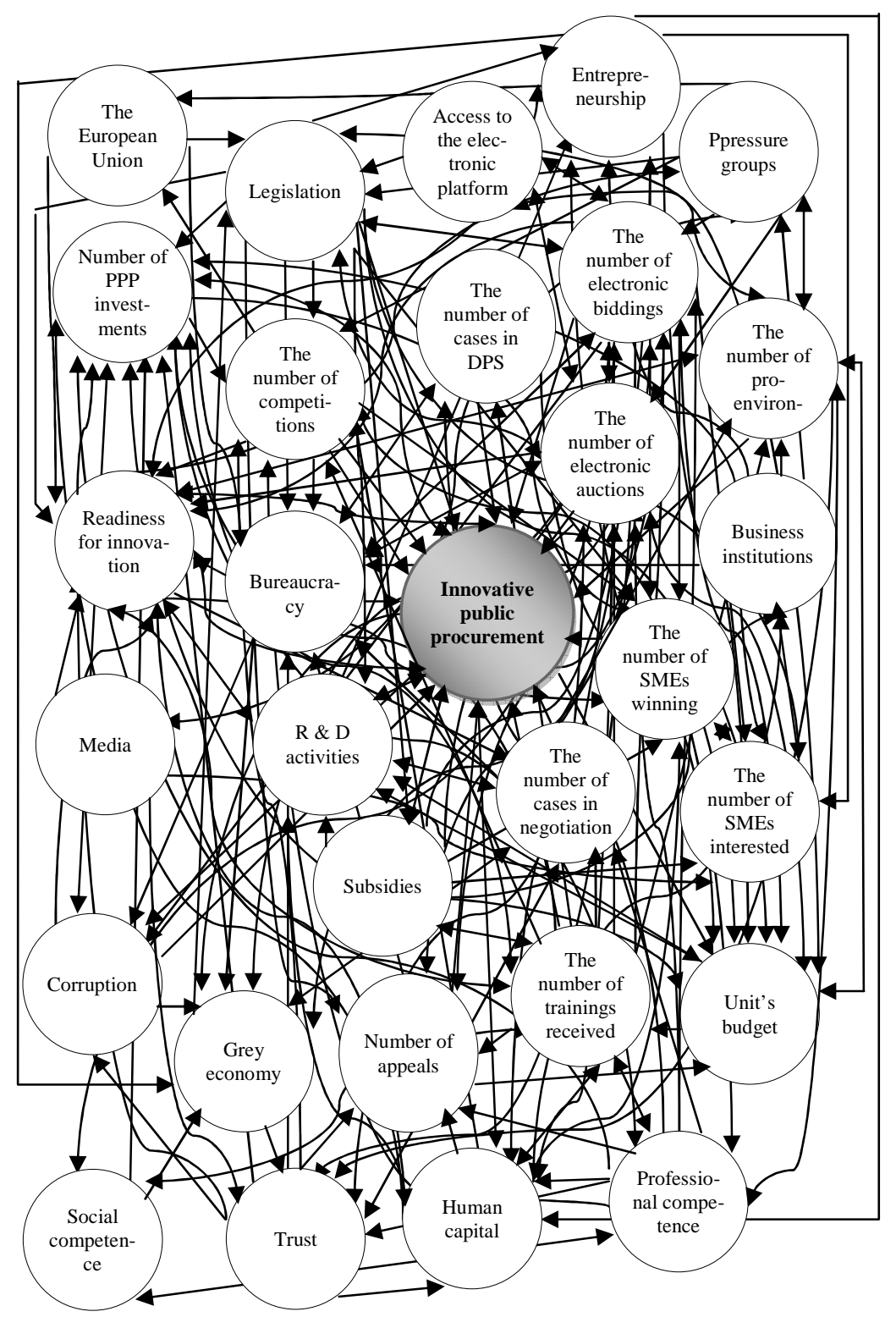

Source: own study. 
Table 1. The matrix of influence

\begin{tabular}{|c|c|c|c|c|c|c|c|c|c|c|c|c|c|c|c|c|c|c|c|c|c|c|c|c|c|c|c|c|c|c|c|}
\hline & 1 & 2 & 3 & 4 & 5 & 6 & 7 & 8 & \begin{tabular}{|l|} 
\\
\end{tabular} & 10 & 11 & 12 & 13 & 14 & 15 & 16 & 17 & 18 & 19 & 20 & 21 & 22 & 23 & 24 & 25 & 26 & 27 & 28 & 29 & 30 & $\begin{array}{c}\text { sum of } \\
\text { A }\end{array}$ \\
\hline 1 & $\mathrm{x}$ & 2 & 0 & 0 & 0 & 0 & 0 & 0 & 0 & 0 & 0 & 3 & 0 & 0 & 0 & 2 & 0 & 0 & 2 & 0 & 0 & 0 & 0 & 0 & 0 & 0 & 2 & 0 & 1 & 1 & 13 \\
\hline 2 & 3 & $\mathrm{x}$ & 3 & 0 & 0 & 0 & 0 & 0 & 0 & 0 & 0 & 0 & 0 & 0 & 0 & 0 & 1 & 3 & 0 & 2 & 0 & 0 & 0 & 0 & 0 & 3 & 0 & 3 & 3 & 0 & 21 \\
\hline 3 & 3 & 0 & $\mathrm{x}$ & 0 & 0 & 0 & 0 & 0 & 0 & 0 & 0 & 3 & 0 & 3 & 0 & 0 & 3 & 0 & 0 & 0 & 0 & 0 & 0 & 0 & 0 & 0 & 0 & 0 & 3 & 0 & 15 \\
\hline 4 & 3 & 0 & 0 & $\mathrm{x}$ & 0 & 0 & 0 & 0 & 0 & 0 & 0 & 0 & 0 & 3 & 0 & 0 & 0 & 0 & 0 & 0 & 0 & 0 & 0 & 0 & 0 & 0 & 0 & 0 & 3 & 0 & 9 \\
\hline 5 & 3 & 0 & 0 & 0 & $\mathrm{x}$ & 2 & 0 & 3 & 3 & 0 & 0 & 3 & 0 & 3 & 0 & 0 & 2 & 2 & 0 & 3 & 3 & 1 & 3 & 3 & 0 & 0 & 1 & 0 & 3 & 0 & 38 \\
\hline 6 & 3 & 0 & 0 & 0 & 0 & $\mathrm{x}$ & 0 & 3 & 3 & 0 & 0 & 3 & 0 & 3 & 0 & 0 & 0 & 0 & 0 & 2 & 3 & 0 & 3 & 3 & 0 & 0 & 1 & 0 & 3 & 0 & 30 \\
\hline 7 & 3 & 0 & 0 & 0 & 0 & 0 & $x$ & 3 & 0 & 0 & 2 & 2 & 0 & 0 & 0 & 0 & 0 & 0 & 0 & 0 & 0 & 3 & 2 & 0 & 0 & 0 & 0 & 3 & 3 & 0 & 21 \\
\hline 8 & 2 & 3 & 3 & 0 & 2 & 2 & 2 & $\mathrm{x}$ & 0 & 1 & 0 & 2 & 0 & 2 & 0 & 2 & 3 & 2 & 3 & 0 & 0 & 0 & 0 & 3 & 0 & 0 & 0 & 0 & 2 & 0 & 34 \\
\hline 9 & 0 & 0 & 0 & 0 & 3 & 3 & 0 & 1 & $\mathrm{x}$ & 0 & 0 & 0 & 0 & 0 & 0 & 0 & 0 & 0 & 0 & 0 & 0 & 0 & 0 & 0 & 0 & 0 & 0 & 0 & 2 & 0 & 9 \\
\hline 10 & 0 & 0 & 0 & 0 & 0 & 0 & 0 & 0 & 0 & $x$ & 0 & 2 & 0 & 0 & 0 & 0 & 2 & 3 & 0 & 0 & 2 & 0 & 0 & 0 & 0 & 0 & 3 & 2 & 2 & 0 & 16 \\
\hline 11 & 0 & 0 & 1 & 0 & 2 & 1 & 2 & 1 & 0 & 0 & $\mathrm{x}$ & 0 & 2 & 0 & 0 & 0 & 0 & 0 & 0 & 0 & 0 & 0 & 0 & 0 & 0 & 0 & 0 & 0 & 0 & 2 & 11 \\
\hline 12 & 2 & 2 & 0 & 0 & 0 & 0 & 3 & 0 & 0 & 3 & 1 & $\mathrm{x}$ & 0 & 0 & 0 & 3 & 3 & 0 & 0 & 0 & 0 & 0 & 0 & 0 & 3 & 3 & 0 & 0 & 0 & 0 & 23 \\
\hline 13 & 0 & 0 & 0 & 0 & 0 & 0 & 0 & 0 & 0 & 0 & 2 & 3 & $\mathrm{x}$ & 0 & 0 & 0 & 0 & 2 & 0 & 0 & 0 & 0 & 2 & 0 & 0 & 0 & 0 & 0 & 0 & 0 & 9 \\
\hline 14 & 3 & 0 & 0 & 2 & 1 & 2 & 0 & 0 & 0 & 0 & 0 & 2 & 0 & $\mathrm{x}$ & 0 & 0 & 0 & 0 & 0 & 3 & 3 & 0 & 0 & 0 & 0 & 0 & 0 & 0 & 0 & 0 & 16 \\
\hline 15 & 0 & 0 & 0 & 0 & 0 & 0 & 1 & 0 & 0 & 1 & 1 & 0 & 0 & 1 & $\mathrm{x}$ & 0 & 0 & 0 & 0 & 0 & 0 & 0 & 0 & 0 & 0 & 0 & 0 & 0 & 0 & 0 & 4 \\
\hline 16 & 3 & 0 & 0 & 0 & 0 & 0 & 0 & 0 & 0 & 2 & 0 & 3 & 0 & 0 & 0 & $\mathrm{x}$ & 0 & 0 & 0 & 0 & 0 & 0 & 0 & 0 & 2 & 0 & 2 & 0 & 0 & 0 & 12 \\
\hline 17 & 2 & 0 & 0 & 0 & 0 & 0 & 0 & 0 & 0 & 3 & 0 & 0 & 0 & 0 & 3 & 0 & $\mathrm{x}$ & 2 & 0 & 0 & 3 & 3 & 0 & 0 & 0 & 0 & 2 & 2 & 0 & 0 & 20 \\
\hline 18 & 0 & 1 & 0 & 0 & 0 & 0 & 0 & 0 & 0 & 0 & 0 & 0 & 0 & 0 & 3 & 0 & 3 & $\mathrm{x}$ & 0 & 0 & 0 & 0 & 0 & 0 & 0 & 0 & 0 & 0 & 0 & 0 & 7 \\
\hline 19 & 2 & 0 & 0 & 0 & 2 & 0 & 0 & 0 & 0 & 1 & 0 & 0 & 0 & 0 & 2 & 3 & 1 & 2 & $\mathrm{x}$ & 0 & 0 & 0 & 0 & 0 & 0 & 2 & 0 & 0 & 3 & 0 & 18 \\
\hline 20 & 2 & 3 & 0 & 0 & 0 & 0 & 0 & 0 & 0 & 0 & 0 & 2 & 0 & 0 & 0 & 0 & 0 & 0 & 0 & $\mathrm{x}$ & 3 & 0 & 0 & 0 & 0 & 0 & 0 & 0 & 0 & 0 & 10 \\
\hline 21 & 0 & 0 & 0 & 0 & 2 & 2 & 0 & 2 & 0 & 0 & 0 & 0 & 0 & 0 & 0 & 0 & 0 & 0 & 0 & 0 & $\mathrm{x}$ & 0 & 3 & 0 & 3 & 0 & 0 & 0 & 0 & 0 & 12 \\
\hline 22 & 0 & 1 & 0 & 0 & 0 & 0 & 0 & 0 & 0 & 0 & 0 & 0 & 0 & 0 & 0 & 0 & 0 & 0 & 0 & 0 & 2 & $x$ & 3 & 0 & 0 & 2 & 0 & 1 & 0 & 0 & 9 \\
\hline 23 & 0 & 3 & 3 & 0 & 0 & 0 & 0 & 0 & 0 & 0 & 0 & 2 & 0 & 3 & 0 & 0 & 0 & 0 & 0 & 3 & 0 & 0 & $\mathrm{x}$ & 3 & 3 & 0 & 3 & 0 & 0 & 0 & 23 \\
\hline 24 & 2 & 0 & 0 & 0 & 0 & 0 & 0 & 0 & 0 & 0 & 0 & 0 & 0 & 2 & 0 & 0 & 0 & 0 & 0 & 0 & 0 & 0 & 0 & $\mathrm{x}$ & 0 & 0 & 0 & 0 & 3 & 0 & 7 \\
\hline 25 & 3 & 0 & 0 & 0 & 0 & 0 & 3 & 0 & 0 & 0 & 0 & 0 & 0 & 3 & 0 & 2 & 0 & 0 & 0 & 0 & 2 & 0 & 2 & 0 & $x$ & 0 & 0 & 0 & 0 & 0 & 15 \\
\hline 26 & 3 & 3 & 3 & 3 & 3 & 3 & 3 & 0 & 0 & 0 & 0 & 3 & 0 & 0 & 0 & 0 & 0 & 0 & 2 & 0 & 0 & 2 & 0 & 3 & 2 & $x$ & 3 & 3 & 0 & 0 & 39 \\
\hline 27 & 3 & 3 & 3 & 0 & 2 & 2 & 0 & 0 & 0 & 0 & 0 & 3 & 0 & 0 & 2 & 2 & 1 & 0 & 0 & 0 & 0 & 0 & 0 & 3 & 0 & 3 & $\mathrm{x}$ & 0 & 0 & 0 & 27 \\
\hline 28 & 0 & 3 & 3 & 3 & 3 & 3 & 3 & 0 & 0 & 2 & 0 & 0 & 0 & 0 & 0 & 0 & 0 & 0 & 0 & 0 & 0 & 1 & 3 & 3 & 3 & 3 & 3 & $x$ & 0 & 0 & 36 \\
\hline 29 & 0 & 2 & 3 & 2 & 2 & 2 & 3 & 0 & 2 & 0 & 0 & 0 & 0 & 0 & 0 & 2 & 0 & 0 & 3 & 0 & 0 & 0 & 0 & 0 & 0 & 3 & 0 & 0 & $\mathrm{X}$ & 0 & 24 \\
\hline 30 & 2 & 0 & 0 & 0 & 0 & 0 & 0 & 3 & 0 & 0 & 0 & 3 & 0 & 3 & 0 & 0 & 0 & 0 & 0 & 0 & 0 & 0 & 0 & 0 & 0 & 0 & 0 & 0 & 0 & $\mathrm{x}$ & 11 \\
\hline $\begin{array}{l}\text { he sum } \\
\text { of } \mathrm{P}\end{array}$ & 47 & 26 & 22 & 10 & 22 & 22 & 20 & 16 & 8 & 13 & 6 & 39 & 2 & 26 & 10 & 16 & 19 & 16 & 10 & 13 & 21 & 10 & 21 & 21 & 16 & 19 & 20 & 14 & 31 & 3 & \\
\hline
\end{tabular}

Source: own study. 
Intensity maps (Figure 2) is a two-dimensional graph wherein the values for the activity of a factor have been placed on the horizontal axis, while those regarding reactivity - on the vertical axis.

The matrix of influence is an indispensable tool for the preparation of the so-called intensity maps. After its creation, it is possible to determine which of the previously separate factors are active, critical, passive or lazy.

Figure 2. Intensity map

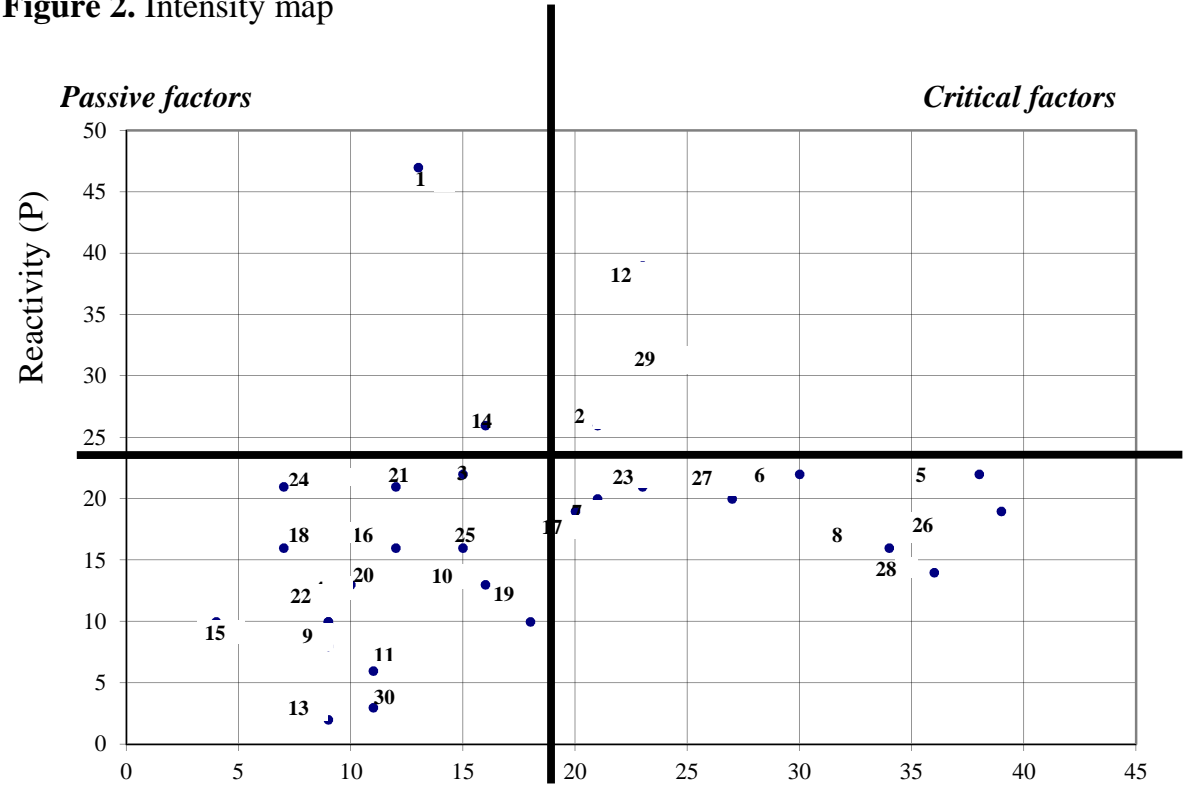

Lazy factors

Active factors

Activity (A)

Source: own study

It is very important to objectively lead the verge of splitting between the categories of factors obtained in the matrix of influence, in order to identify active, critical, passive and lazy factors. It is assumed that the dividing lines will extend in places that are formed by dividing the maximum value of $\mathrm{A}$ and $\mathrm{P}$ by 2 . Thus obtained values are $\mathrm{A}=19.5$ and $\mathrm{P}=23.5$.

On the basis of the intensity maps it is possible to finally emerge active, critical, passive and lazy factors. Table 2 shows the distribution of these factors along with the values for the activity and reactivity. 
Table 2. Summary of factors affecting the implementation of innovative public procurement

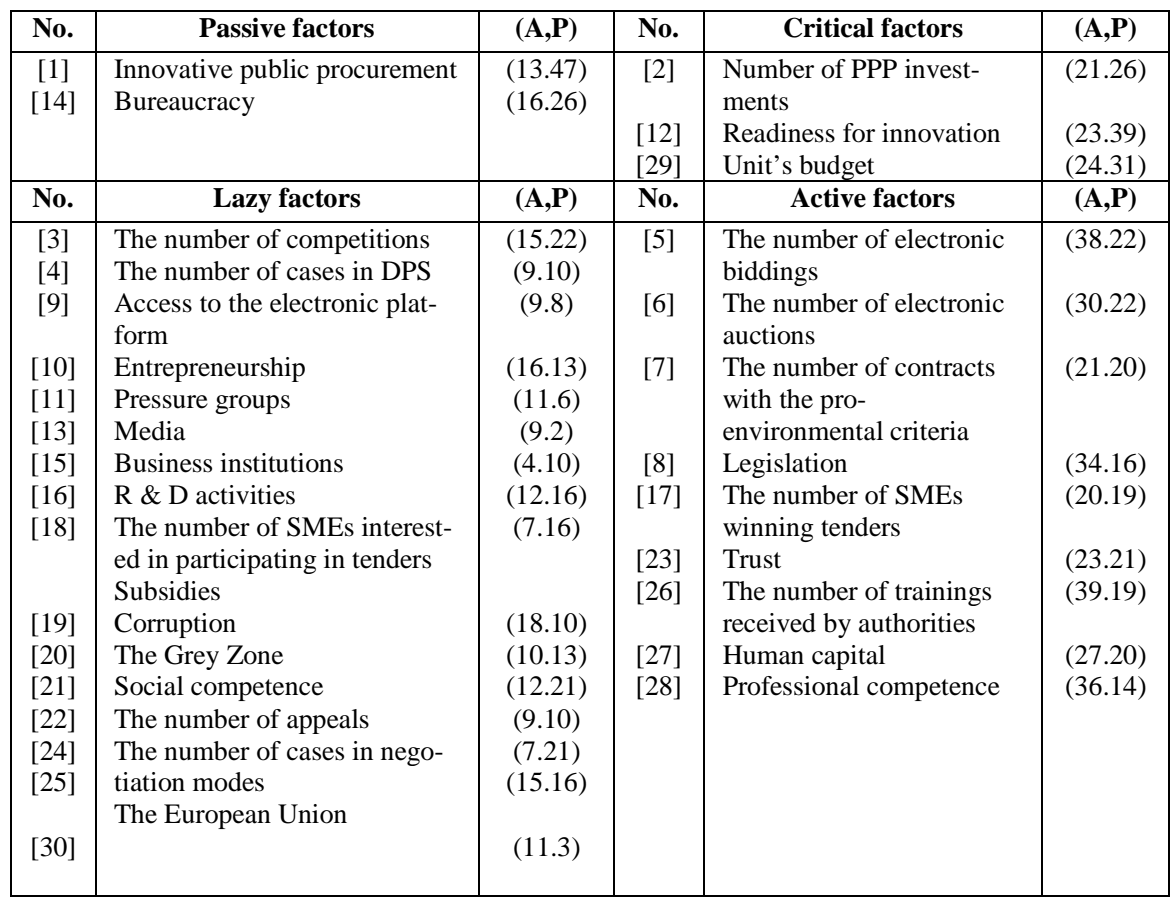

Source: own study.

The maps of intensity show that there are three critical factors that strongly influence other elements, but are also heavily influenced themselves. However, it seems that only the first and the last (the number of PPP investments and the unit's budget) may be under the control of public administration. On the other hand, the individual unit's budget depends in its income part on the distribution of funds by the government and the local government and to some extent the contracting authority does not affect it. By using it, this institution can cause considerable changes especially if it allocates an essential part of the funding in innovation. Today the structure of the budget is dominated by expenditure on the wages of employees.

The second group of factors (and the most desirable from the point of view of creating demand for innovative public procurement) is the group of nine active factors. They strongly affect innovative public procurement and, most importantly, they are not subject to strong influences themselves. Among these factors, there was legislation that - like previously the unit's budget - does not depend directly on the actions of the contracting authori- 
ty, but may, however, play a very important role in creating the demand for modern supplies, services or construction works.

The next step in the deployment of network thinking methodology in the process of creating a model to evaluate the innovativeness of public administration entities that create demand for public procurement should be to determine which critical and active factors are manageable and nonmanageable, and which can be measured. Thus, it is necessary to use the following factors: the number of PPP investments, willingness to innovate, the unit's budget, the number of electronic biddings, the number of electronic auctions, the number of orders with the pro-environment criteria, legislation, the number of SMEs winning tenders, confidence, the number of trainings received by authorities, human capital, professional competence.

To objectively assess changes in a public administration unit, and thus in the whole national economy, it is necessary to rely primarily on such factors which are directly influenced by the audited entity. Therefore, the starting point in the selection of the factors used for its evaluation should be the ability to influence them by deliberate actions taken by this entity's management.

Such reasoning results in a situation where it is necessary to use only the manageable factors, separated within the framework of network thinking methodology. They include: the number of PPP investments, unit's budget, the number of electronic biddings, the number of electronic auctions, the number of pro-environmental contracts, the number of trainings received by authorities and professional competence.

Of the seven aforementioned factors, two are critical (the number of PPP investments and the unit's budget), while other remain active. Therefore, the critical factors strongly influence other elements, but they are also subject to a strong influence and their weight in the model of innovativeness assessment must be smaller as it is difficult to predict the effects associated with their use. Therefore, one should be very careful in using these factors, which may not necessarily be related to the reluctance of officials to introduce innovative solutions in public procurement.

In order to select the weight of various factors involved in the model evaluating the innovativeness of public administration entities awarding public contracts, one can use a methodology based on the proprietary model of analytical hierarchy (Borowiec, 2008).

The assessment of the validity of individual factors in this model will be based primarily on the strength of activities they possess, read from the matrix of influence developed in this chapter. Table 3 contains a list of manageable factors with their assignment to a specific group, and an indi- 
cation of the strength of their influence (activity) regarding the other factors included in the network of public procurement system.

Table 3. Manageable factors in the construction of a model for assessing the innovativeness of Polish public administration entities awarding public contracts

\begin{tabular}{|l|c|c|}
\hline A manageable factor & Group of factors & Factor activity \\
\hline Number of PPP investments & Critical & 21 \\
\hline Unit's budget & Critical & 24 \\
\hline The number of electronic biddings & Active & 38 \\
\hline The number of electronic auctions & Active & 30 \\
\hline The number of pro-environmental contracts & Active & 21 \\
\hline The number of trainings received by authorities & Active & 39 \\
\hline Professional competence & Active & 36 \\
\hline
\end{tabular}

Source: own study.

As it can be seen from Table 3, the most important factors in terms of the impact on other components of the system are: a number of trainings received by authorities and the number of electronic biddings. Most problems arise with the factor related to technical competence. They are understood in the literature in very different ways and exhibit significant difficulties for the process of measurement. For example, A. Pocztowski believes that competence is a broader concept of qualification and includes the total assets of human characteristics that make up a causal link with high or above average effects of work, which have a universal dimension (Rostkowski, 2004). In addition to knowledge, there are also: loyalty, trustworthiness, honesty, perfectionism and self-improvement. Yet another definition is given by M. Armstrong - according to him, competencies include what an employee should know, what he or she should do and how to do it (Whiddett, Hollyford, 2003).

It can be assumed that professional competence is strongly related to knowledge received by employees. Therefore, the model assumes that the analyzed factors: the number of trainings received by authorities and professional competence are highly similar to each other. However, since the first one can be expressed in a very simple manner by means of a measurable value, in the construction of the model the second one can be skipped. Finally, six variables were incorporated into the analytical hierarchy method used to determine the weights of individual factors included in the model.

To objectify the values resulting from comparisons, it is necessary on the basis of Table 3 to determine the relationships between factors in terms of their activities and bring them down to the values used in the method of 
analytical hierarchy. Table 4 shows the relationships between the factors, resulting from dividing their activity by itself.

Table 4. Relationships between the factors associated with their activity

\begin{tabular}{|c|c|c|c|c|c|c|}
\hline & $\begin{array}{l}\text { The } \\
\text { number } \\
\text { of PPP } \\
\text { invest- } \\
\text { ments }\end{array}$ & $\begin{array}{l}\text { Unit's } \\
\text { budget }\end{array}$ & $\begin{array}{c}\text { The } \\
\text { number } \\
\text { of elec- } \\
\text { tronic } \\
\text { biddings }\end{array}$ & $\begin{array}{c}\text { The } \\
\text { number } \\
\text { of elec- } \\
\text { tronic } \\
\text { auctions }\end{array}$ & $\begin{array}{c}\text { The } \\
\text { number } \\
\text { of pro- } \\
\text { envi- } \\
\text { ronmen- } \\
\text { tal } \\
\text { con- } \\
\text { tracts }\end{array}$ & $\begin{array}{l}\text { The } \\
\text { number } \\
\text { of train- } \\
\text { ings } \\
\text { received } \\
\text { by au- } \\
\text { thorities }\end{array}$ \\
\hline $\begin{array}{l}\text { The number of PPP } \\
\text { investments }\end{array}$ & 1 & 0.87 & 0.55 & 0.7 & 1 & 0.54 \\
\hline The unit's budget & 1.14 & 1 & 0.63 & 0.8 & 1.14 & 0.61 \\
\hline $\begin{array}{l}\text { The number of } \\
\text { electronic biddings }\end{array}$ & 1.81 & 1.58 & 1 & 1.27 & 1.81 & 0.97 \\
\hline $\begin{array}{l}\text { The number of } \\
\text { electronic auctions }\end{array}$ & 1.43 & 1.25 & 0.79 & 1 & 1.43 & 0.77 \\
\hline $\begin{array}{l}\text { The number of pro- } \\
\text { environmental } \\
\text { contracts }\end{array}$ & 1 & 0.87 & 0.55 & 0.7 & 1 & 0.54 \\
\hline $\begin{array}{l}\text { The number of } \\
\text { trainings received by } \\
\text { authorities }\end{array}$ & 1.86 & 1.62 & 1.03 & 1.3 & 1.86 & 1 \\
\hline
\end{tabular}

Source: own study.

As it is apparent from the table, the maximum value obtained in the comparison of the various factors with each other is 1.86 . This means that it should correspond to the value of "9", which arises from the comparison of two factors, one of which is predominant over the other. Since the minimum value in the method of analytical hierarchy is the number "1", we should calculate the difference between the maximum value (1.86) and this number and divide the result obtained by 9 , assigning consecutive intervals with individual severities. The severities obtained in this way, which correspond to the different intervals, can be found in Table 5 . 
Table 5. Intervals corresponding to the degrees of importance (severities) in the method of analytical hierarchy

\begin{tabular}{|c|c|}
\hline The obtained range of values & Severity \\
\hline $1.00-1.07$ & 1 \\
\hline $1.08-1.16$ & 2 \\
\hline $1.17-1.26$ & 3 \\
\hline $1.27-1.36$ & 4 \\
\hline $1.37-1.46$ & 5 \\
\hline $1.47-1.56$ & 6 \\
\hline $1.57-1.66$ & 7 \\
\hline $1.67-1.76$ & 8 \\
\hline $1.77-1.86$ & 9 \\
\hline
\end{tabular}

Source: own study.

Now in place of the values in the various ranges it is necessary to assign the respective values of Table 4 with the corresponding degrees of importance (severities) of Table 5. Apart from values $<1$ we obtain data summarized in Table 6.

Table 6. Severity levels resulting from the comparison of the activity of factors

\begin{tabular}{|l|c|c|c|c|c|c|}
\cline { 2 - 6 } \multicolumn{1}{c|}{} & $\begin{array}{c}\text { Number } \\
\text { of PPP } \\
\text { invest- } \\
\text { ments }\end{array}$ & $\begin{array}{c}\text { The } \\
\text { unit's } \\
\text { budget }\end{array}$ & $\begin{array}{c}\text { The } \\
\text { number } \\
\text { of elec- } \\
\text { tronic } \\
\text { biddings }\end{array}$ & $\begin{array}{c}\text { The } \\
\text { number } \\
\text { of } \\
\text { elec- } \\
\text { tronic } \\
\text { auctions }\end{array}$ & $\begin{array}{c}\text { The } \\
\text { number } \\
\text { of pro- } \\
\text { envi- } \\
\text { ronmen- } \\
\text { tal } \\
\text { con- } \\
\text { tracts }\end{array}$ & $\begin{array}{c}\text { The } \\
\text { number } \\
\text { of train- } \\
\text { ings } \\
\text { received } \\
\text { by } \\
\text { authori- } \\
\text { ties }\end{array}$ \\
\hline $\begin{array}{l}\text { The number of PPP } \\
\text { investments }\end{array}$ & 1 & & & & 1 & \\
\hline The unit's budget & 2 & 1 & & & 2 & \\
\hline $\begin{array}{l}\text { The number of } \\
\text { electronic biddings }\end{array}$ & 9 & 7 & 1 & 4 & 9 & \\
\hline $\begin{array}{l}\text { The number of } \\
\text { electronic auctions }\end{array}$ & 5 & 3 & & 1 & 5 & \\
\hline $\begin{array}{l}\text { The number of pro- } \\
\text { environmental } \\
\text { contracts }\end{array}$ & 1 & & & & 1 & \\
\hline $\begin{array}{l}\text { The number of } \\
\text { trainings received by } \\
\text { authorities }\end{array}$ & 9 & 7 & 1 & 4 & 9 & 1 \\
\hline
\end{tabular}

Source: own study.

Since, as noted earlier, the number of PPP investments and the unit's budget both are critical factors, which may involve a high risk of adverse reactions, it is necessary to increase the importance of other factors in rela- 
tion to these criteria. It was assumed, therefore, that each factor in comparison to critical factors will have an extra degree of severity added to it. By adding a severity level in comparing the number of orders and the number of environmentally-friendly PPP investments, the ratio between the number of PPP investments and the number of pro-environmental contracts changed, and it is its inverse. Analogously, the degree of severity resulting from the comparison of the unit's budget to the number of proenvironmental contracts should be reduced by 1 , so that these factors become equivalent.

Simultaneously, the missing degrees of severity in Table 6 are the inverse ratio of those degrees that are already in the matrix. For example, the ratio of the number of electronic auctions and the number of trainings received by authorities is the inverse of the degree obtained as the ratio of the number of trainings to the number of auctions. Thus, it amounts to $1 / 4$. After making the necessary corrections and additions we received the data presented in Table 7.

Table 7. Severity levels resulting from the comparison of the activity of factors

\begin{tabular}{|l|c|c|c|c|c|c|}
\cline { 2 - 7 } & $\begin{array}{c}\text { Number } \\
\text { of PPP } \\
\text { invest- } \\
\text { ments }\end{array}$ & $\begin{array}{c}\text { The } \\
\text { unit's } \\
\text { budget }\end{array}$ & $\begin{array}{c}\text { The } \\
\text { number } \\
\text { of elec- } \\
\text { tronic } \\
\text { biddings }\end{array}$ & $\begin{array}{c}\text { The } \\
\text { number } \\
\text { of elec- } \\
\text { tronic } \\
\text { auctions }\end{array}$ & $\begin{array}{c}\text { The } \\
\text { number } \\
\text { of pro- } \\
\text { envi- } \\
\text { ronmen- } \\
\text { tal } \\
\text { contracts }\end{array}$ & $\begin{array}{c}\text { The } \\
\text { number } \\
\text { of train- } \\
\text { ings } \\
\text { received } \\
\text { by au- } \\
\text { thorities }\end{array}$ \\
\hline $\begin{array}{l}\text { The number of PPP } \\
\text { investments }\end{array}$ & 1 & $1 / 2$ & $1 / 9$ & $1 / 6$ & $1 / 2$ & $1 / 9$ \\
\hline The unit's budget & 2 & 1 & $1 / 8$ & $1 / 4$ & 1 & $1 / 8$ \\
\hline $\begin{array}{l}\text { The number of } \\
\text { electronic biddings }\end{array}$ & 9 & 8 & 1 & 4 & 9 & 1 \\
\hline $\begin{array}{l}\text { The number of } \\
\text { electronic auctions }\end{array}$ & 6 & 4 & $1 / 4$ & 1 & 5 & $1 / 4$ \\
\hline $\begin{array}{l}\text { The number of pro- } \\
\text { environmental } \\
\text { contracts }\end{array}$ & 2 & 1 & $1 / 9$ & $1 / 5$ & 1 & $1 / 9$ \\
\hline $\begin{array}{l}\text { The number of } \\
\text { trainings received } \\
\text { by authorities }\end{array}$ & 9 & 8 & 1 & 4 & 9 & 1 \\
\hline
\end{tabular}

Source: own study. 
After filling the matrix, it is necessary to calculate the $6^{\text {th }}$ degree root value of the product of numbers within it. The degree of the root always depends directly on the degree of the matrix. The result is:

- for the number of PPP investments $\sqrt[6]{1 \cdot \frac{1}{2} \cdot \frac{1}{9} \cdot \frac{1}{6} \cdot \frac{1}{2} \cdot \frac{1}{9}}=0,283$,

- for the unit's budget $\sqrt[6]{2 \cdot 1 \cdot \frac{1}{8} \cdot \frac{1}{4} \cdot 1 \cdot \frac{1}{8}}=0,445$,

- for the number of electronic bidding $\sqrt[6]{9 \cdot 8 \cdot 1 \cdot 4 \cdot 9 \cdot 1}=3,706$,

- for the number of electronic auctions $\sqrt[6]{6 \cdot 4 \cdot \frac{1}{4} \cdot 1 \cdot 5 \cdot \frac{1}{4}}=1,399$,

- for the number of pro-environmental contracts $\sqrt[6]{2 \cdot 1 \cdot \frac{1}{9} \cdot \frac{1}{5} \cdot 1 \cdot \frac{1}{9}}=0,413$

- for the number of trainings for authorities $\sqrt[6]{9 \cdot 8 \cdot 1 \cdot 4 \cdot 9 \cdot 1}=3,706$.

The next step in determining the weights of factors included in the model for the assessment of innovativeness of public administration units awarding public contracts is summing these values:

$$
0,283+0,445+3,706+1,399+0,413+3,706=9,952
$$

Calculating the sum allows for the calculation of optimal percentage weights for the factors included in the model:

- the number of PPP investments: $(0,283 / 9,952) 100 \%=2,84 \%$,

- the unit's budget: $(0,445 / 9,952) 100 \%=4,47 \%$,

- the number of electronic biddings: $(3,706 / 9,952) 100 \%=37,24 \%$,

- the number of electronic auctions: $(1,399 / 9,952) 100 \%=14,06 \%$,

- the number of pro-environmental contracts: $(0,413 / 9,952) 100 \%=$ $4,15 \%$

- the number of trainings for authorities: $(3,706 / 9,952) 100 \%=37,24 \%$. Having determined the percentage weight of each factor included in the model, we can proceed to its presentation. Its final form has been shown in Table 8. 
Table 8. Model for assessing the innovativeness of Polish public administration entities awarding public contracts

\begin{tabular}{|c|c|c|c|}
\hline Factor & The method of calculation (a) & Weight (b) & $\begin{array}{c}\text { The result (a x b) } \\
{[\%]}\end{array}$ \\
\hline $\begin{array}{l}\text { The number of PPP } \\
\text { investments }\end{array}$ & $\begin{array}{l}\text { the number of orders leading to } \\
\text { contracts in the form of PPP / } \\
\text { total number of cases }\end{array}$ & $2,84 \%$ & $\ldots \times 2,84 \%=$ \\
\hline The unit's budget & $\begin{array}{l}\text { the amount of the expenses } \\
\text { associated with the purchase of } \\
\text { innovative procurement / total } \\
\text { public procurement expenditure }\end{array}$ & $4,47 \%$ & $-\mathrm{x} 4,47 \%=$ \\
\hline $\begin{array}{l}\text { The number of elec- } \\
\text { tronic biddings }\end{array}$ & $\begin{array}{l}\text { the number of cases in the elec- } \\
\text { tronic bidding / total number of } \\
\text { cases }\end{array}$ & $37.24 \%$ & $\ldots$ X $37.24 \%=$ \\
\hline $\begin{array}{l}\text { The number of elec- } \\
\text { tronic auctions }\end{array}$ & $\begin{array}{l}\text { the number of cases using elec- } \\
\text { tronic auction / total number of } \\
\text { cases }\end{array}$ & $14.06 \%$ & $-\mathrm{x} 14.06 \%=$ \\
\hline $\begin{array}{l}\text { The number of pro- } \\
\text { environmental con- } \\
\text { tracts }\end{array}$ & $\begin{array}{l}\text { the number of cases with pro- } \\
\text { environmental criteria / total } \\
\text { number of cases }\end{array}$ & $4.15 \%$ & $-\mathrm{x} 4.15 \%=$ \\
\hline $\begin{array}{l}\text { The number of train- } \\
\text { ings received by } \\
\text { authorities }\end{array}$ & $\begin{array}{l}\text { the number of trainings related to } \\
\text { innovative public procurement / } \\
\text { total number of trainings received } \\
\text { by employees }\end{array}$ & $37.24 \%$ & $-\mathrm{x} 37.24 \%=$ \\
\hline $\begin{array}{l}\text { the sum of innova- } \\
\text { tiveness }\end{array}$ & & & \\
\hline
\end{tabular}

Source: own study.

As regards the interpretation of the results obtained from the use of the model, it looks as follows:

- the results in the range of $100 \%-76 \%$ - the highest innovativeness,

- the results in a range of $75 \%-51 \%$ - high innovativeness,

- the results in the range of $50 \%-26 \%$ - moderate innovativeness,

- the results in the range of $25 \%-0 \%$ - low level of innovativeness.

Such a division is supported primarily by the European Union guidelines, which (for example in the field of green public procurement) planned to obtain the number of $50 \%$ of cases by the end of 2010. It is recommended to carry out the calculations associated with the use of the model on an annual basis by comparing the results with those of the previous year. This will provide an opportunity to indicate the direction of changes in the development of innovativeness in the analyzed entities awarding public contracts.

Since each model should be validated, also in this case the two units of public administration got their innovativeness indicators calculated. These entities were local government bodies performing similar functions in Po- 
land and Germany ${ }^{3}$. The data were obtained during an interview conducted with the leadership of departments responsible for public procurement and on the basis of data collected by the audited entities. The obtained results are shown in Table 9.

Table 9. The use of the model to assess innovativeness in the selected units of public administration

\begin{tabular}{|l|c|c|c|c|c|c|}
\hline \multirow{2}{*}{ Factor } & \multicolumn{3}{|c|}{ Polish Unit } & \multicolumn{3}{c|}{ German Unit } \\
\cline { 2 - 7 } & Ratio & Weight & Result & Ratio & Weight & Result \\
\hline LIPP $_{\mathrm{PP}}$ & 0 & $2.84 \%$ & $0 \%$ & 0.03 & $2.84 \%$ & $0.08 \%$ \\
\hline BJ & 0.08 & $4.47 \%$ & $0.36 \%$ & 0.22 & $4.47 \%$ & $0.98 \%$ \\
\hline LLE & 0.031 & $37.24 \%$ & $1.15 \%$ & 0.23 & $37.24 \%$ & $8.56 \%$ \\
\hline LAE & 0.076 & $14.06 \%$ & $1.07 \%$ & 0.17 & $14.06 \%$ & $2.39 \%$ \\
\hline LZP & 0.006 & $4.15 \%$ & $0.02 \%$ & 0.24 & $4.15 \%$ & $1.00 \%$ \\
\hline LSZ & 0.12 & $37.24 \%$ & $4.47 \%$ & 0.51 & $37.24 \%$ & $18.99 \%$ \\
\hline $\begin{array}{l}\text { Total } \\
\text { Innovativeness }\end{array}$ & \multicolumn{7}{|c|}{$\mathbf{7 . 0 7 \%}$} & \multicolumn{3}{c}{} \\
\hline
\end{tabular}

Source: own study based on test results.

As indicated by the data obtained on the basis of the research on public administration in Poland and Germany, the native unit belongs to institutions that create low innovativeness, while the German one to those of moderate innovativeness. In both cases, there is a visible distance that has to be covered to catch up with the guidelines of the European Union. In fact, in the use of all the factors that create innovativeness, the Polish unit is still lagging behind its German counterpart. The largest differences can be seen especially in the use of green public procurement (the Polish unit generates only $0.6 \%$ compared to $24 \%$ on the German side), the number of electronic auctions (3.1\% and $23 \%$ of cases respectively), and the number of trainings received by authorities characterized by issues related to the factors included in the model (12\% and 51\% respectively). The Polish example shows how much still remains to be done in terms of utilization of the factors that create demand for innovative procurement and how big distance separates our country from our western neighbours regarding work on improving the innovativeness of the entire national economy.

\footnotetext{
${ }^{3}$ The validation was conducted during the research internship in Germany.
} 


\section{Conclusions}

The resulting model has allowed positive verification of the hypothesis wagered at the outset. The analysis showed that there are factors that are controllable and active and are able to influence the improvement of economic innovativeness through public sector procurements. Moreover, the model of measuring innovativeness of Polish public administration institutions based on public procurement by using the network thinking methodology has made it possible to achieve the objective of the article.

The resulting model can play an important role in economic policymaking related to the allocation of state funds to the state administration entities throughout the country. In such application, it can also act as an incentive function of these units because the results obtained in terms of innovativeness may influence future revenues associated with the development of regions or investment for local communities.

The annual assessment conducted by the entity or by a system that allows the introduction of online data will also allow the determination of the average level of innovativeness in public administration units dealing with procurement in the entire country.

Undoubtedly, it is important in this area to take appropriate legislative action, because as foreign experiences shows, only quick and efficient calculation of the rate of innovativeness allows for an appropriate use of the model. Therefore, its use is simplified to the maximum and does not require multiple procedures.

The model should also be applied to the micro level, because each unit of public administration can use it to monitor their progress in the purchase of more modern supplies, services and construction works. It is also of major importance in the use of electronic tools and the so-called green public procurement, whose weight is not large, but can be decisive in a situation when public entities maximize the number of trainings and the use of electronic tools.

Finally, we should mention the fundamental principle of economics associated with the use of the model. Using it ensures optimal results with the utilization of given resources. For example, it is difficult to imagine that while using the model, the money received by entities would be allocated to the trainings of employees not related to raising awareness on creating demand for innovative public procurement. This solution also seems to be a kind of a remedy for the lack of knowledge of contracting in the area related to negotiating procurement modes and the procedures of public-private partnerships. 
The use of public-private partnership forced by the model is linked to another macroeconomic benefit. The use of this tool provides significant relief for the state budget expenditures related to the development of infrastructure and public services by replacing public capital with the private one. The benefits obtained this way can also translate into the desired concentration on the entire lifecycle of a given project, as in the case of proceedings conducted in the PPP efficiency and effectiveness formula, which are not counted for in the individual stages, but in relation to the total integrated cost throughout the lifecycle of the project. Finally, the big advantage associated with the launch of PPP in Poland on a larger scale is the acceleration and improvement of the efficiency of project implementation. This is just an example of the benefits associated with the use of this tool.

The use of the model can also help to change the attitude of authorities in the field of environmental protection. Awarding these contracts and the associated influx of budgetary funds resulting from an increased innovativeness of certain units can successfully compensate for the often higher expenses they incur in connection with the purchase of green products and services.

Ultimately, there is also a chance to change the image of public administration. There is a still lingering notion that it is outdated and does not pass on good practices in the area of creating demand for innovative products and services to the private sector. It is worth mentioning that this change may lead to a greater confidence of citizens in these units as well as the entire economic system of the state.

Analyzing the importance of the manageable factors in the presented model, one can get an impression that only two of them dominate (the number of electronic biddings and the number of trainings received by authorities). In fact, these factors (given the results) seem to be crucial in conjunction with the next phase of network thinking methodology associated with the planning of strategies and actions. They provide the launch of processes associated with the use of electronic tools, which (as indicated by numerous examples) allow for huge savings of budgetary funds (which can be used for the purchase of modern products and services), as well as the efficient use of public funds for training of employees of public administration in Poland. Therefore, they essentially play a huge economic role as they allow obtaining significant savings not only in the administration of public institutions, but also in the entire state budget.

The model also carries certain limitations. Not every tender procedure can be carried out using the formula of public-private partnerships or as electronic bidding. The legislature has imposed limitations and only some of the proceedings can be realized in this way. It is also difficult to expect 
that the staff of the unit providing public contracts will be trained in the use of only the procedures associated with obtaining innovative products and services in public tenders. There exists a whole range of other activities that require the improvement of knowledge such as formulating the terms of reference, selecting criteria and procedures for evaluating an offer or judicial appeal proceedings that do not involve raising innovative procedures, but are necessary for the smooth functioning of individuals.

Moreover, not all procurements have their ecological equivalents. Also, it is not always possible to analyze the balance of benefits and costs associated with them and maintain their green nature.

A threat to the use of the model can also lie in the so called "rat race" between public authorities striving for the greatest proportion of the budget regarding expenses related to tenders. This may result, among other things, in management trying to enforce participation in trainings on employees withdrawing them from their daily duties and causing backlogs in the current work.

It is worth mentioning that the created model does not provide guidelines for creating innovations on the supply side of public procurement market. As we know innovation-oriented companies may find the problems that P.M. Simpson divided into four categories: too many changes for the sake of change, market risk, hostile attitude of the staff or an increase in costs (Simpson, Siguaw, Enz, 2006). Innovativeness of companies of different sizes may also be influenced by various factors such as, for example, the structure of the market (Audretsch, 1995), (Malerba, Orsenigo, 1996). These facts mean that in the future, it will be necessary to undertake a study on the construction of a model for assessing the innovativeness of enterprises participating in the public procurement market.

\section{References}

Audretsch, D. B.(1995). The Propensity to Exit and Innovation. Review of Industrial Organization, 10(5), http://dx.doi.org/10.1007/BF01026884.

Borowiec, A. (2008). Zamówienia publiczne jako instrument wspierania matych $i$ średnich przedsiębiorstw w Polsce. Poznań: Politechnika Poznańska.

Freeman, Ch. (1994). The Economics of Technical Change. Cambridge Journal of Economics, 18(5).

Gmurczyk, J.(2014). Innowacyjność polskiej gospodarki. Stan obecny i rekomendacje. Warszawa: Instytut Obywatelski

Malerba, F., \& Orsenigo, L.(1996). Schumpeterian Patterns of Innovation are Technology-specific. Research Policy. 25(3), http://dx.doi.org/10.1016/00487333(95)00840-3. 


\section{Arkadiusz Borowiec}

Romer, P. M. (1986). Increasing Returns and Long-run Growth. Journal of Political Economy, 94(5), http://dx.doi.org/10.1086/261420.

Rostkowski, T. (2014). Nowoczesne metody zarzadzania zasobami ludzkimi. Warszawa: Difin.

Simpson, P. M., Siguaw J. A., \& Enz C. A.(2006). Innovation orientation outcomes: The good and the bad. Journal of Business Research. 59(10-11), http://dx.doi.org/10.1016/j.jbusres.2006.08.001.

Schumpeter, J. (1995). Kapitalizm, Socjalizm, Demokracja. Warszawa: Wydawnictwo Naukowe PWN.

Urząd Zamówień Publicznych (2014). Sprawozdanie o funkcjonowaniu systemu zamówień publicznych w 2013 roku. Warszawa

Whiddett, S., \& Hollyforde, S.(2003). Modele kompetencyjne $w$ zarzadzaniu zasobami ludzkimi. Kraków: Oficyna Ekonomiczna. 